\title{
Minimizing Distance Using Just-in-Time Teaching and Flipped Classroom
}

\author{
Mahmuda Akhter \\ BRAC University, Dhaka, Bangladesh
}

\begin{abstract}
JiTT (Just-in-Time Teaching) and flipped classroom are two innovations in academia where high-tech and no-tech resources are blended to encourage more interaction and creativity among students. These two methods also help minimize the dependency on face-to-face lecture and make the class time more creative and effective. This study is the very first attempt of implementing these strategies in Bangladesh. It explores the prospect of JiTT and flipped classroom at tertiary level in Bangladesh. In the first part of this paper, recent studies on JiTT and flipped classroom are discussed to shed light on their effectiveness and problems. The latter part explains the data and research findings. Before collecting the data, JiTT and flipped classroom were used with 33 students of undergraduate level who were students of "ELT Methodology" course. After the implementation of the methods, a questionnaire survey was conducted to collect data regarding their response to these two methods. The study reveals that JiTT and flipped classroom help cover more topics in a short time while enhancing students' interaction and participation. They make students come to the class prepared and reflect on their learning. Teachers can understand students need better and provide required feedback. The overall interaction among students and teachers can be improved using JiTT and flipped classroom since everyone is clear about each other’s existing knowledge and learning objectives.
\end{abstract}

Keywords: just-in-time, technology, teaching strategies, flipped classroom, video lecture

\section{Introduction}

The future role of technology in education is a matter of debate among the teachers, administrators, and students. Most of them would agree that technology will change education in the future. However, the argument lies in how it will change education and whether it will bring a positive change or negative change. Novak, Patterson, Garvin, and Christian (1999) came up with a new blend of technology and traditional teaching named "Just-in-Time Teaching" (JiTT) that was appreciated by all interested groups. According to them, JiTT is a teaching and learning strategy based on the interaction between web-based study assignments and active learners' classroom. Students respond to an online reading/assignment before the class and the instructor reads students' responses "just in time" to adjust classroom lesson according to their needs. On the other hand, in a flipped classroom, learners listen to the lecture sitting at home and do the assignment in classroom with the help of their teachers and peers (Bishop \& Verleger, 2013). Several studies (Gavrin, 2006; Ruddick, 2012; Tucker, 2012) have shown that both JiTT and flipped classroom can be used to enhance learners' active participation and minimize dependency on face-to-face class.

At the beginning of 2014, Bangladesh was going through some political unrest that resulted in strikes and

Mahmuda Akhter, lecturer, MA in ELT, Department of English and Humanities, BRAC University. 
blockades. Therefore, students missed a number of classes and it became difficult to finish the syllabus within the semester. That situation made the author to think of using JiTT and flipped classroom strategies to complete the syllabus within due time while ensuring students' learning and active participation. However, the underlying purposes of this study was to explore the benefits and problems of JiTT and flipped classroom at tertiary level in Bangladesh and how these two strategies can be used to lessen dependency on physical presence in a classroom while enhancing learners' participation.

\section{JiTT and Its History}

JiTT is an innovative way of increasing interactivity in the classroom and engaging learners in the learning process (Gavrin, 2006). It is a "fusion of high-tech and low-tech elements" (ibid) where WWW (i.e., high-tech element) is used to deliver materials and initiate communication among students and teachers. Low-tech side put emphasis on classroom interaction among them. The underlying method is to involve the students into some warm-up tasks and allow the teachers to make necessary adjustment in their lessons depending on learners' need.

The term JiTT is a reminiscent of Toyota, a famous automobile company, who used "Just-in-Time" manufacturing process to enhance flexibility and responsiveness of their operation (Monden, 1998). In this process, goods are produced in small quantities to meet the instant market demand and raw materials and parts are purchased in small quantities to be used just in time for production. Thus, each delivery is smaller and contains only the materials that are specifically needed for short-term function, instead of large infrequent deliveries that address the average needs. Using this analogy of automobile production, Gavrin, Watt, Marrs, and Blake (2004) developed a pedagogical system called JiTT. It also emphasizes only on the students' specific needs and does not waste time repeating the things that they already know.

\section{How JiTT Works}

In a traditional classroom, a teacher comes to the class with some preplanned activities but while executing the tasks, he/she finds them to be very easy or tough for the students. The teacher often repeats the topics that students already know that result to a boring atmosphere in the classroom. To change the mood of the class completely, JiTT allows both the teachers and students to do some collaborative homework before coming to the class. Rather than starting a lecture from scratch, students participate in some warm-up tasks and discussion through WWW. Usually, the teacher provides some reading materials and online exercises that students need to read and complete before attending the class. The teacher goes through their responses to identify the areas students face problems or grasp easily. Based on the observation, he/she will decide the amount of time to be spent in class on various topics. In this way, they can ensure that they spend enough time on a difficult topic and do not repeat the same thing. Gavrin (2006) mentions that students' performance in the warm-up tasks helped him understand the "current state" of the students and he worked to improve them to his desired level.

\section{Flipped Classroom}

The idea of flipped classroom derived from one simple question - what is the best way of utilizing face-to-face time with students? (Bergmann \& Sams, 2012). Flipped classroom is pedagogical model in which the role of homework and typical lecture is reversed (EDUCAUSE, 2012). It has become popular particularly 
for the availability of audio and video materials on any subject in a virtual classroom (Herreid \& Schiller, 2013). Unlike traditional classroom, in a flipped classroom model what is normally done in classroom and what is normally done at home are switched. Instead of listening to lectures in class and doing homework at home, students watch video lectures and read relevant materials at home and spend the class hour doing problem solving activities in collaboration with their peers and teachers.

Ruddick's (2012) research findings show that the students of flipped classroom outperformed the students of traditional classroom in their final exams. She implemented flipped instruction in a chemistry class. Her study further reveals that students of flipped classroom felt less intimidated about chemistry and found the online lectures and PowerPoint slides very useful. Kay and Kletskin (2012) found from their mathematics course that students prefer video podcasts or lectures since they find it easy to follow and helpful to understand any new concepts. Zappe, Leicht, Messner, Litzinger, and Lee (2009) flipped a large undergraduate architecture classroom. Their students reported that flipped classroom is more enjoyable than traditional classroom and they can cover more topics within a short time while ensuring active participation of everyone. Teachers in Fulton's (2012) study made almost a revolution using flipped classroom. In her study, the math teachers of a high school in Minnesota flipped their math classes to suffice the lack of textbook and they derived the following benefits:

(1) Students can work at their own comfort zone. In a lecture-based class, weak students struggle to understand their teachers and sometimes the strong students find repetition of what they already know. But, the lecture is videoed, they "breeze through" it or watch over and over it needed.

(2) When students did their math homework in classroom, teachers got better idea of students' problems and provided effective feedback.

(3) Classroom time was used more creatively and effectively and students had access to multiple teachers' expertise since all the videos were open to all the students.

(4) Parents could also have a look into their children's coursework and performance.

(5) Teachers also enhanced their professional development through the process of creating and sharing videos.

Herreid and Schiller (2013) mentioned some pitfalls of flipped classroom. Firstly, students who are new to the method might show resistance since they have to study at home before attending any class. Moreover, if any student comes to the class without preparation, he/she might face problem in doing the activities. Secondly, creating a video might be an extra burden for the teachers. Finding a suitable and good quality video from other source is also very difficult. However, in Tucker's (2012) study, almost all the teachers agreed that it is not the instructional video but how they are integrated into the overall process that makes the difference. Therefore, preparation before conducting a flipped classroom is very crucial. Bergmann and Sams (2012) proposed to consider the following issues before flipping a class:

(1) It is better to collaborate with other colleagues instead of doing it alone. They mentioned a virtual network (flippedclassroom.org) where all the flipped classroom teachers can meet.

(2) Since it is a different way of teaching, it is very important to get support from the administrators. Support from the IT department is also necessary, as the method is very much dependent on technology.

(3) Before flipping their classes, teachers should give enough time to learn the new software and other technical aspects.

(4) Thoughtfulness is the most important thing needed to be a successful flipped classroom teacher. The teachers need to understand their individual context and adapt their flipped model accordingly. 


\section{Methodology}

The current study is explorative in nature since it is the very first of its kind in Bangladesh. Based on the other pieces of research conducted in different countries, this study attempts to explore the scope and prospect of JiTT and flipped classroom in Bangladeshi setting. A survey was conducted to collect data from the participants and the data are analyzed to find-(1) students' attitude to JiTT and flipped classroom and (2) pros and cons of these teaching styles.

\section{Participants}

Since the study focuses on the tertiary level, 33 undergraduate students of English department were selected for collecting data and all of them were doing the course "ELT Methodology". The students were quite competent in using technology. Almost every student had internet access from their home and around 70\% students (23 out of 33) had smart phones with internet.

\section{Data Collection Procedure}

For the purpose of data collection, JiTT and flipped classroom were applied in the classroom for one month to cover four chapters of the syllabus. There were eight classes in one month where four of them were JiTT classroom and the others were flipped classroom.

In case of JiTT, the reading materials and relevant tasks or quizzes were uploaded in Moodle (a learning management system) and students had to go through them before coming to the class. Sometimes, they also participated in online discussion based on their readings. The teacher used to go through their responses before the class and prepared lessons according to that. Later, the students took part in classroom activities.

Lectures for flipped classroom were videoed in the university's media lab. Relevant PowerPoint slides were also incorporated with the videos. Ideally, videos are uploaded in web but due to connectivity problem, the lectures were not uploaded. The students collected them from media lab and after going through them, participated in in-class tasks.

After one month of implementation, a survey was conducted among the students to know their responses and feedback to these new strategies. It is to be noted here that Moodle was used as a learning management system for this study and students were quite efficient in using Moodle since they also used it for other courses. But, it was the first time that technology was blended with real classroom teaching.

\section{Findings}

Results from the current study are presented in two frameworks. The first one sheds light on students' attitude towards JiTT and flipped classroom and the next one talks about the pros and cons of these strategies and makes some recommendations.

\section{Students' Attitude to JiTT and Flipped Classroom}

Research findings show that 20 students out of 33 thought that JiTT and flipped classroom were helpful for them. Ten students partially agreed with them but they also opined that it would vary depending on the contents. Flipped classroom might not be effective if the contents are difficult to understand. The rest three students were not so optimistic about these teaching styles.

Most of the students (25 out of 33) mentioned the following benefits of JiTT and flipped classroom:

(1) They can cover more topics within a short time. Usually the teacher lectures in one class and in the next class, they have discussion or practical tasks but in these strategies, they can participate actively from the first class. 
(2) The new teaching strategies make them to participate in the classroom. In traditional setting, they do not need to come to the class prepared since the teacher is going to explain everything. However, while following JiTT and flipped classroom, they have to attend classes with preparation and that helps them to understand and critically analyze teacher's lecture and actively participate in the discussion.

(3) JiTT and flipped classroom discourage them to come to the class with a blank head. They come with a minimum preparation to participate in the discussion or task. However, they also consider it as an extra-load.

(4) They feel free to agree or disagree in online discussion (that was a warm-up task in JiTT), which they cannot do in a face-to-face discussion, since they prefer to maintain harmony among their peers. The overall interaction among students and teacher was improved in these methods.

(5) The students were very happy about the fact that they can listen to the recorded lecture whenever they want to. In a lecture-based class, they have to write down everything and if they miss something, they get confused. On the other hand, in a flipped classroom, they are provided with the video lecture and they can listen to it and repeat whenever they need. Six students further said that they can carry the lectures in their mobile phone or tab and listen to it on the way to their university.

The survey ended with an optimistic note that out of 33 students, 29 students (almost 88\%) said that they would like to have this type of blend in future in other courses. They found it to be very exclusive and dynamic and it allowed them to work in their comfort zone.

\section{Problems of the Methods}

All the students agreed that they did not face any problem to follow teacher's instruction. Even if there was any confusion, they asked their friends to clarify.

Regarding technical problems, 18 (54.5\%) students mentioned that, due to slow internet connection, they faced problem in downloading the materials from Moodle. One student said that it was her first experience with Moodle so it took time for her to cope up with this LMS (Learning Management System).

Ten students mentioned that if the content is new or difficult to them, JiTT and flipped classroom instruction might not be effective. Rather, it will be a "burden" for them to understand the contents on their own and prepare for the classroom participation. It also might be frustrating since it is the "teachers' job" to make things clear to the students.

Two students mentioned that these methods expect learners to be tech-savvy but in reality that might not be the case. They further stated that for the successful implementation of JiTT and flipped classroom, it is necessary to have 24-hour internet access, which every student does not have.

\section{Recommendations}

The study attempts to make some recommendations on how these strategies can be adapted to derive more benefits from them. In the survey, 21 students made the following suggestions to improve the teaching strategies. The rest could not suggest any.

(1) The recorded lectures can be uploaded in Moodle (even though it is time consuming) so that they can access them from home.

(2) The instruction for in-class assignment can be given online so that they can come prepared.

(3) Since all of them are regular Facebook user, Facebook can be incorporated in learning and teaching, like Moodle.

(4) The lectures can be recorded with the help of students. It will motivate them and make them engaged 
into the learning process.

(5) The power-point slides need to be more interactive as the virtual class lacks direct interaction among teacher and students.

\section{Conclusion}

It was reported by EDUCAUSE (2012) that reflection is crucial to ensure effective learning, which students cannot do in a traditional lecture based classroom because they have to capture the contents instantly. The report further says that devoting the class time in application of the concepts will help the teachers identify students' errors and provide timely feedback. Considering this research claim and the then political situation of the country, this study was conducted to use JiTT and flipped classroom in Bangladesh and explore their prospects at tertiary level. Therefore, the participants were selected from undergraduate level and a survey was conducted after the successful implementation of the methods. The survey results reveal that JiTT and flipped classroom exerts positive influence in the students. They agreed that these methods help them to be more engaged into the learning process. They get the chance to reflect on what they are learning. Their overall response showed that they find JiTT and flipped classroom to be dynamic, smart and engaging way of teaching. They also expressed their interest to have this combination in future in the other courses. They further made some recommendations to implement the methods more successfully in future. After analyzing all their responses, it can be claimed that students hold a positive attitude towards JiTT and flipped classroom and these strategies can be used to lessen dependency on physical presence or face-to-face interaction while enhancing active participation virtually.

\section{References}

Bergmann, J., \& Sams, A. (2012). Before you flip, consider this. The Phi Delta Kappan, 94(2), 25.

Bishop, J., \& Verleger, M. (2013, June). The flipped classroom: A survey of the research. Paper presented at 120th ASEE Annual Conference and Exposition, Atlanta, Georgia.

EDUCAUSE Learning Initiatives. (2012). 7 things you should know about flipped classroom. Retrieved from https://net.educause.edu/ir/library/pdf/ELI7081.pdf

Fulton, K. P. (2012). 10 reasons to flip. The Phi Delta Kappan, 94(2), 20-24.

Gavrin, A. (2006). Just-in-Time-Teaching. Metropolitan Universities Journal, 17(4), 9-18.

Gavrin, A., Watt, J., Marrs, K., \& Blake, R. (2004). Just-in-time-teaching (JiTT): Using the web to enhance classroom learning. Computers in Education Journal, 14(2), 51-59.

Herreid, C. F., \& Schiller, N. A. (2013). Case studies and the flipped classroom. Journal of College Science Teaching, 42(5), 62-66.

Kay, R., \& Kletskin, I. (2012). Evaluating the use of problem-based video podcasts to teach mathematics in higher education. Computers and Education, 59, 619-627

Monden, Y. (1998). Toyota production system: An integrated approach to just-in-time. Norcross, GA: IIE Press.

Novak, G., Patterson, E., Garvin, A., \& Christian, W. (1999). Just in Time Teaching: Blending active learning with web technology. NY: Prentice Hall.

Ruddick, K. W. (2012). Improving chemical education from high school to college using a more hands-on approach (Unpublished doctoral dissertation). University of Memphis.

Tucker, B. (2012). The flipped classroom: Online instruction at home frees class time for learning. Education Next, 12(1), 82-83.

Zappe, S., Leicht, R., Messner, J., Litzinger, T., \& Lee, H. (2009). "Flipping” the classroom to explore active learning in a large undergraduate course. Proceeding of the 2009 American Society for Engineering Education Annual Conference \& Exhibition. 